\title{
Opportunities for the School System to Instill Environmental Values
}

\author{
Azizah Husin, Abdullah Saleh \\ Faculty of Teacher Training and Education, Sriwijaya University, Inderalaya, Indonesia \\ Email: azizahhusin50@gmail.com,dullascurtin42@gmail.com
}

How to cite this paper: Husin, A. and Saleh, A. (2019) Opportunities for the School System to Instill Environmental Values. Journal of Environmental Protection, 10, 1649-1656.

https://doi.org/10.4236/jep.2019.1012098

Received: August 26, 2019

Accepted: December 17, 2019

Published: December 20, 2019

Copyright (อ 2019 by author(s) and Scientific Research Publishing Inc. This work is licensed under the Creative Commons Attribution International License (CC BY 4.0).

http://creativecommons.org/licenses/by/4.0/

(c) (i) Open Access

\begin{abstract}
This study aims to reveal the opportunities for schools to educate environmental values. This research uses qualitative methods. Data collection techniques use observation, interviews and literature studies. The research subject is the teacher and focus of the research is what of availability in the school system that enables teacher to have the opportunities to educate student about values of environmental caring. Analysis uses data reduction, primary school teachers are taken randomly. Data analysis uses descriptive qualitative analysis. Technical data analysis uses data reduction, verification and conclusion drawing. The results showed that schools have a great opportunity to be utilized for the education of environmental values. These opportunities are: vision and mission of school orientation, school curriculum, extracurricular activities, educational interactions, commemoration of holidays, rewards and punishments, conventions, school physical environment, rules and norms, school slogans. It is suggested that schools in this case (school principals) socialize these opportunities and utilize the opportunities available in schools effectively and efficiently used for environmental value education.
\end{abstract}

\section{Keywords}

School, Values, Environment

\section{Introduction}

The living environment increasingly requires joint efforts to overcome existing problems. With a population that is getting bigger and denser, it will accelerate the environment to experience degradation. Many problems caused by human actions cause environmental damage. If it is not reduced, then the behavior will not be controlled [1] [2]. The Nature is to be used for human benefit. If nature is damaged, it will come back to humans themselves in the future. Under these 
conditions, collaborative efforts by all parties are needed to reduce environmental damage. School institutions have a strategic role to carry out education full of environmental values. The Directorate General of Primary and Secondary Education of the Ministry of Education and Culture also continues to encourage the development and stabilization of the implementation of environmental education [3] in schools, among others through teacher upgrading, promoting the environmental service month. On July 5, 2005, the Minister of Environment and the Minister of National Education issued a joint decree number: 07/MenLH/06/2005 No 05/VI/KB/2005 for development of environmental education. Formal educational institutions have a system consisting of components: [4] the school environment includes physical environment, social environment and academic environment. The physical environment of the school, school facilities, the environment around the school, the social environment, the relationship of students with teachers, students and school staff who work together in maintaining school cleanliness, have a clean, shady and comfortable school environment, school rules [5]. The results of this study [6] indicate that: 1) school-based environmental policies are seen from the vision and mission of the school, a personal development program consisting of routine school activities, spontaneous activities, exemplary and conditioning. 2) The environment-based school curriculum includes integration in subjects. 3) Participatory-based school policies are seen from extracurricular activities, namely the UKS (School Health Enterprises) and KIR (Youth Scientific Activities). Along with Fullday School, the child is more and more in the school system. The atmosphere of education occurs as long as the child is in school, because the child is in a situation that is conditioned to be ready to accept all the values of education and learning. The school has a character development task. At school there are 18 character values [7] that must be educated and developed in students. Among these values is the value of environmental stewardship. The facts above provide opportunities for schools to carry out character education efficiently and effectively. Schools are a place for knowledge transfer and prepare generations to be able to participate in society. At school a process of facilitating learning, skills, value development and habituation occurs [8]. The results of the study [6] [9] show that: schools already have their own strategies in achieving Adiwiyata schools among which there are long, medium and short term plans, the implementation of schools through participatory activities through Friday programs includes, Friday Believers, Serious Friday, Healthy Friday, Loving Friday and Innovative Friday. Participatory-based environmental activities with school residents are by inviting student guardians to do activities. Environmental Education is an effort to change behaviors and attitudes aimed at increasing knowledge, skills and awareness of the community about environmental values and issues of environmental problems [10] [11]. The value of caring for the environment in schools still does not get enough attention even though the school has considerable opportunities to make the value of the environment increase so that it becomes the character of students [8] and [12]. School is a place of educa- 
tion that is loaded with educational values. If utilized optimally, these opportunities can make schools environmentally friendly. Children are in school for a long time every day of the week. From the start of school hours to returning home in the afternoon. The value of environmental education can occur to students either through interaction, school atmosphere, conditioning, and discipline, norms developed at school, moments or anniversaries. Researchers want to find out whether schools as an education system have opportunities to instill environmental values.

\section{Research Methods}

This study uses an explorative approach. This study seeks to explore opportunities that exist in the school system that can be utilized to instill environmental values in students (aspects related to important components in school such as teacher, student, student teacher interaction, curriculum/subjects, commemoration activities, extracurricular activities, the goals/vision of the school mission, school rules and discipline, message from the slogan). Reseach was done in 6 months at two primary schools in Palembang. Research method uses descriptive qualitative method. The subjects of the research are two primary schools include the teacher in there. Interviewed were held to the teachers who taken by random sampling technique. Observation was done to see the opportunities in the physical environment that teachers could use for environmental education: school yard/yard, plants around, school walls, rest rooms, classrooms to make writing slogans containing messages to protect cleanliness and the environment; non physical/social (communication), written message: cleanliness rules, punishment for those who do wrong to the environment and gifts for those who always do good to the environment. And curriculum for subjects to educate about the content of environmental values (containing environmental content). Data analysis techniques namely: data collection, data display, data reduction for the uncorrelated data, and drawing conclusions. Data analysis techniques following this procedure: at first researcher collected data taken from interview and observation and literature. After data had collected, and data were displayed to check whether data wasn't fit with need of research. And then researcher found some data didn't need it, so those data reduced. The last step is the result of the data is clear by verification data. The last step is it can be taken conclusion.

\section{Research Result}

The primary school that we used for the site of this research, were public primary school in Palembang, those are No: 21, 21, and 57. The school has sircumstance and that isn't green at all, some small part planted with flowers in the pot. Some areas planted by plants. As normal, the school has vision and mission. School has extracurricullar programs. The schoolyard isn't so wide, but enough for student play aoutside and do sport exercise. Each school has 20 teachers.

Based on the results of interviews with teachers obtained information that 
educational opportunities for environmental value in students can also be obtained from the use of extracurricular activities. There are extra-curricular activities which are routine one semester, but there are occasional ones, and some are deliberately programmed specifically for certain needs, including if related to government policies such as the Adiwiyata program (go green school). In this school special programs and activities for the environment are accidentally carried out. Religious Studies taught provide basic values of doing well, but for values concerning the environment have not been used/not yet associated. Likewise, the interview with the PPKN learning teacher, that the values contained in the Civic Education are given scientifically but do not relate to other values specifically, especially with environmental values.

In the social studies subject, namely the environment, more focused on environmental science and knowledge, the value of how students should behave with the environment is conveyed, not specific to the value of the environment.

The Ministry of Education and Culture has 18 values that exist in schools to become the basis and guidelines for student character development. The character values are: religious, tolerance, discipline, workhard, creative, selphelp, democracy, curioucity, nationalism, love the country, respect of achievement, communicative, love peace, love reading, environmental concern, social care, and responsible. The values that can shape the character of children in school are one of the 18 values from the Ministry of Education and Culture which is environmental concern. Vision and mission of the school do not have to be explicit about environmental cleanliness and go green schools such as government policies so that schools implement the go green program. The vision and mission of the school can implicitly include green, beautiful and clean schools. From the school that is seen it does not clearly describe the green school message. In the social studies subject, namely the environment, more focused on environmental science and knowledge, the value of how students should behave with the environment is conveyed, not specific to the value of the environment.

\section{Discussion}

From the results of the study showed that school has many opportunities to instill environmental values. It turns out that the opportunity is not realized and also the impact is not utilized by the teacher/school to be oriented to shape the value of caring for the environment. One of the tasks of the teacher is to educate students to shape the character of caring for the environment [9]. The school is an educational institution, has the main task of education and learning in aspects of cognitive (knowledge), affective (values development), and habituation/character formation [10]. In one week children who are in regular school, spend time at school approximately 40 hours. All the time in school student activities are conditioned towards educational purposes. Schools in this case the principal and teachers guide students in a good direction. The length of time at school can be utilized by teachers on "go green" activities for children. Activities 
undertaken to instill the value of the environment are to familiarize children to maintain environmental cleanliness, greening. The government through the Ministry of Environment launched a "go green" school program [12]. This program needs to get support from all elements of the school namely human resources to take advantage of all the opportunities/potential inherent in the school. Subjects affect the planting of values. In addition for children having values, there are subjects that are full of values namely religion, moral of Pancasila (state ideology) as can be seen in Table 1. Subjects with environmental content, integrated into the subjects of natural sciences and social sciences. Actually do not really talk about environmental values, the material content more cognitive orientation. However, if the teacher convey the values from the sub environmental material, then the student is more absorbed and has influenced a positive attitude to care for the environment. Event or also the day of commemoration as a source of ideas for implementing environmental values. Commemoration of World Environment Day, Earth Day, World Water Day and others. The teacher can take advantage of this moment because something that will be welcomed to be commemorated, can be an idea to make what activities can be raised so that the warning becomes more internalized so that it is more beneficial. Schools can carry out movements, environmental awareness programs conducted by students and driven by teachers. The day of commemoration of the environment aims to increase students' awareness to care about the environment.

Table 1. Grid school opportunities that can be utilized for environmental value planting.

\begin{tabular}{|c|c|c|c|}
\hline Indicator & Sub Indicator & Discriptor & Method \\
\hline $\begin{array}{l}\text { 1) School Physical } \\
\text { Environment }\end{array}$ & $\begin{array}{l}\text { 1) the content of the } \\
\text { writing slogan in a } \\
\text { certain place }\end{array}$ & $\begin{array}{l}\text { school yard/yard, plants } \\
\text { around, school walls, rest } \\
\text { room, class room }\end{array}$ & observation \\
\hline $\begin{array}{l}\text { 2) Social and non } \\
\text { physical } \\
\text { environment }\end{array}$ & $\begin{array}{l}\text { 2) Teacher-student } \\
\text { communication } \\
\text { 3) Commemoration of } \\
\text { special holidays } \\
\text { especially } \\
\text { environmental } \\
\text { days etc. }\end{array}$ & $\begin{array}{l}\text { Teacher educative student } \\
\text { interactions weigh on } \\
\text { environmental values } \\
\text { Commemorate the big day } \\
\text { by slipping the message of } \\
\text { the living environment } \\
\text { pesan }\end{array}$ & $\begin{array}{l}\text { Interview, } \\
\text { observation }\end{array}$ \\
\hline $\begin{array}{l}\text { 3) School } \\
\text { functions }\end{array}$ & $\begin{array}{l}\text { 4) Curriculum/ } \\
\text { Subjects in class } \\
\text { 5) Vision and Mission } \\
\text { of the School } \\
\text { 6) Extracurricular } \\
\text { 7) School regulations/ } \\
\text { discipline }\end{array}$ & $\begin{array}{l}\text { 1) Value of concern for the } \\
\text { environment }\end{array}$ & $\begin{array}{l}\text { Literature and } \\
\text { curriculum } \\
\text { studies, } \\
\text { interviews, } \\
\text { observations }\end{array}$ \\
\hline $\begin{array}{l}\text { Academic } \\
\text { environment }\end{array}$ & $\begin{array}{l}\text { 1) Curriculum } \\
\text { (knowledge and } \\
\text { values) } \\
\text { 2) Method-reward and } \\
\text { punishment }\end{array}$ & $\begin{array}{l}\text { Subjects in Social Science, } \\
\text { Religion and Civic } \\
\text { Education. }\end{array}$ & $\begin{array}{l}\text { Literature, } \\
\text { Ministry of } \\
\text { Education and } \\
\text { Culture } \\
\text { policies and } \\
\text { Environment }\end{array}$ \\
\hline
\end{tabular}


Those days included June 5, world environmental day, April 22 Earth day, Earth day 21 March World water day. These days are often commemorated by the Ministry of Environment [13] and the Ministry of Education and Culture [3]. By carrying out this activity, children become aware of and need to care for and care for the environment. Even though not directly with environmental day, you can also use important day commemoration like independence day, Kartini day, National Education Day, Mother's day. All of that can be used as a moment for competition in writing, painting, poetry, and participation in environmental cleanliness and greening schools. School can do such activities as greening, composting, cleanliness competition. The main program/orientation of the school is to emphasize environmental preservation/go green [8]. If the school is oriented through its vision and mission, the spirit and activities of the school lead to the achievement of the vision and mission without showing other programs. This can happen because every program from an institution/school has links to other programs. Visi mission will be contained in the program and action. The positive impact of the main program of the school will provide facilities/infrastructure, facilities and policies as well as funds/budget for the environment. The greening program comes from the plans of teachers and school principals and can also come from the goals, orientation and vision and mission of the school to aim at how-oriented schools. If the vision and mission of the school do not incorporate green and clean and beautiful values, then in the implementation of daily school activities affect whether the school will develop schools go green or not. In schools the teacher and student communication take place at any time in the school either through teaching and learning, or informal communication outside of classroom activities. This communication can be filled with the weight of the value of environmental education. Planting environmental values can be done through reprimands, orders, prohibitions, warnings, rewards and punishments against students who take actions related to carried out or violated them or in accordance with and not in accordance with the values of the environment. Many occurrences/times where the child does something positive and/or negative towards an object related to the environment so the teacher must take educational action. When the teacher sees the student littering, the teacher immediately reprimands and asks to take the trash to be placed in the right place from the box garbage provided. When the teacher sees the student not turning off the water after using it, the teacher will warn the student and explain simply to save water. Slogans containing short deaf-san on the wall, on a board mounted in certain places, can also be used to instill environmental values. For example, don't step on grass. The child will later understand that grass is planted for greening and beauty. The value embedded in a child's soul is the value of environmental protection and protection. The impact is the child begins to avoid stepping on the grass and even starts reprimanding from other friends who do it. The message conveyed in the slogan is charged with educating environmental values. Call for example in the toilet room is written "keep clean by flushing the toilet after use": "keep the school clean", "cleanliness 
is half of faith", do good and love for living beings, "love and care for animals", "plants are the lungs -the world". The school creates conditions for students in the atmosphere of education and learning. This condition is very easy to motivate students to comply with the school system even more if the school has a commitment to schools that care about the environment. Behavioristic theory says that learning is a change in behavior. Someone is considered to have learned if he is able to change his behavior in accordance with educational objectives. This theory shows how important stimulus is in the form of conditions created and the response obtained from the creation of the concession. The school atmosphere is the atmosphere of education. The teacher is authorized to educate and teach, while students are obliged to learn and the right to get an education with knowledge competence, values, behavior and skills. This is a potential force or energy to be directed at environmental awareness commitments.

School rules/norms can also be utilized as a potential for planting environmental values such as: following the rules not to litter, there is a schedule of picketing to water the plants, maintaining care in class, toilets, in the school yard/yard, not stepping on grass, discipline watering plants, not damaging plants, not vandals ie scribble on walls, and others. If you violate, you will get a penalty. If the most obedient get an award [14] and [15]. Educational methods used are reward and punishment, orders and prohibitions, praise, good examples, and habituation. Teachers can give rewards if students do good deeds or are friendly to the environment. Conversely the teacher can do the punishment if the student does an act that is not good for the environment in a way that is littering by creating a clean environment.

\section{Conclusion}

From the research results obtained indicate that the opportunity for schools to instill the value of the environment is quite large. Students stay in school for a long time in an atmosphere conditioned by education and learning. So values can basically be educated in the school system itself namely the curriculum, the school's physical environment and the non-physical environment of the school. The school opportunity is in the form of special subjects and value requirement subjects namely Religion and Citizenship Education, Extracurricular activities, school mission/vision goals, school regulations, student teacher interactions, slogans, reward punishment methods, commemoration of public holidays, especially the environment, the formation of 18 school character values, one of which is the value of environmental care that must be taught at school. It is suggested that the school principal disseminates this opportunity to the teacher so that the teacher uses it in the school environment to make the school care for the environment.

\section{Conflicts of Interest}

The authors declare no conflicts of interest regarding the publication of this paper. 


\section{References}

[1] Uno, I. and Djamal, Z. (2010) Prinsip-prinsip ekologi ekosistem, Lingkungan dan Pelestariannya. Bumi Aksara, Jakarta.

[2] Keraf, S.A. (2006) Etika lingkungan. Kompas, Jakarta.

[3] Kemendikbud (2011) Karakter nilai pendidikan. https://issuu.com/download-bse/docs/wamendiknas di rembug nasional pendidik an 2011

[4] Dewi, D. (2014) Pendidikan Lingkungan Hidup. UNS, Semarang.

[5] Hasbullah (2013) Dasar-dasar Ilmu Pendidikan. Rajawali Pers, Jakarta, 46.

[6] Soeryani (2007) Pendidikan lingkungan siswa sekolah dasar dan menengah: Harmoni Kehidupan di Alam Smesta. IPPL, Jakarta.

[7] Nurcahyaty, R. (2018) Nilai-Nilai Pendidikan Karakter Bangsa Indonesia dan Contohnya.

https://ranahteknologi.wordpress.com/2018/01/02/18-nilai-nilai-pendidikan-karakt er-bangsa-indonesia

[8] Madura, M.K. (2019) Gerakan Peduli Lingkungan Harus Dimulai dari Sekolah.

[9] Lickona (2015) Mendidik Untuk Membentuk Karakter: Bagaimana Sekolah dapat Mengajarkan Sikap Hormat dan Tanggung Jawab: Ja-karta. Bumi Aksara, Jakarta.

[10] Azmi, F. and Elfayetti, E. (2017) Analisis Sikap Peduli Lingkungan Siswa Melalui Program Adiwiyata Di SMA Negeri 1 Medan. Geografi, 9, 125-132.

https://doi.org/10.24114/jg.v9i2.6901

[11] Hidayatullah (2017) Implementasi Program Adiwiyata Melalui Kegiatan Lingkungan Berbasis Partisipatif Di Smp Negeri 1 Pandaan. Inspirasi Manajemen Pendidikan, 5, 6-9.

[12] Kementerian Negara Lingkungan Hidup dan Kementerian Pendidikan dan Kebudayaan (2011) Panduan Adiwiyata Sekolah Peduli dan Berbudaya Lingkungan. https://id.scribd.com/doc/185890174/Buku-panduan-Adiwiyata-2011-final-pdf

[13] Batbual, A. (2017) Sekolah di Asmat Ajarkan Siswa Peduli Ling-kungan Sejak Tingkat Dasar.

https://www.mongabay.co.id/2017/1A2/01/sekolah-di-asmat-ajarkan-siswa-peduli-1 ingkungan-sejak-tingkat-dasar/5

[14] Purwanti, D. (2017) Pendidikan Karakter Peduli Lingkungan Dan Implementasinya SDN 1 Pohkumbang Karanganyar Kebumen. Jurnal Riset Pedagogik Dwijacendekia, 1, 14-20. https://jurnal.uns.ac.id/jdc

[15] Rizky Dewi Iswari, S.W. and Utomo (2017) Evaluasi Penerapan Program Adiwiyata Untuk Membentuk Perilaku Peduli Lingkungan di Kalangan Siswa (Kasus: SMA Negeri 9 Tan-gerang Selatan dan MA Negeri 1 Serpong). Jurnal Ilmu Lingkungan, $15,35-41$.

https://www.researchgate.net/publication/316947871 Evaluasi Penera-pan Progra m Adiwiyata Untuk Membentuk Perilaku Peduli Lingkungan di Kalangan Sis wa Kasus SMA Negeri_9 Tangerang Selatan dan_MA Negeri_1 Serpong 